\title{
Phytochemical Screening and Analysis of Carica papaya, Agave americana and Piper nigrum
}

\author{
Pallavi Singh*, Nainika Tanwar, Trisha Saha, Aishwarya Gupta and Sargam Verma \\ Department of Biotechnology, College of Engineering and Technology, IILM Academy of \\ Higher Learning, Greater Noida, Uttar Pradesh-201306, India
}

*Corresponding author

\section{Key words \\ Phytochemical screening, Larvacidal activity, Carica papaya, Agave americana, Piper nigrum}

\section{Article Info}

Accepted:

17 January 2018

Available Online:

10 February 2018

\section{A B S T R A C T}

In today's world all the medicinal plants found on the earth have their unique medicinal usages and significances. Their usage is increasing day by day in our daily lives. There are various simple and cheap methods available for finding out about the various medicinal uses medicinal plants contain many bioactive compounds that can be used in the process of curing various human diseases to identify these compounds one can perform the phytochemical screening of various parts of any specific plant. Phytochemicals are nonnutritive chemicals that occur naturally in various types of medicinal plants during metabolic process. They can be used as poisons or as a traditional medicine. In our present study we selected the three medicinal plants: Carica papaya, Piper nigrum, Agave americana, two types of leaves and roots extract were prepared for the phytochemical screening i.e. methanolic extract, aqueous extract (water). All the three selected plants were known for their medicinal properties, and they are widely used for the different types of purposes in pharmaceutical sciences. Agave americana is a well-known plant for their larvacidal activity, skin burns, cuts, injury. It has been reported that Carica papaya is used for the treatment for malaria, is a rich flora in Nigeria. Piper nigrum is used for the various purposes in day to day life for curing sore throat, fever, cold, widely used in various cough syrups also. Phytochemical screening of these medicinal plants showed maximum presence of alkaloids, phenols, sugar, proteins, flavonoids in both the extracts. But, methanolic extracts showed best results than the aqueous one. Presence of saponin only detected in the methanolic extracts. As in aqueous extract, moderate amount of terpenoids and quinones are present.

\section{Introduction}

Since, the ancient time herbs and medicinal plants are known for their infinite useful properties and from generations people are dependent on it. Hundreds or thousands of new drugs are form from the medicinal plants (Amany et al., 2012). Medicinal plants have the presence of bioactive chemicals or phytochemical constituents that occur naturally in plants and are widely used for various pharmacological purposes (Parekh and Chanda, 2008). Most of the bioactive constituents (phytochemical constituents) present in leaves, roots, stem, barks that have defense mechanism and provide protection for various diseases some of them are:- alkaloids, terpenoids, flavonoids, sugar, proteins, 
saponins, phenols and tannins, quinones. Phytochemical constituents are of two types primary (proteins, amino acids, sugar, chlorophyll etc) and secondary constituents (alkaloids, terpenoids, phenols, flavonoids, etc) (Abdullahi et al., 2013; Aiyegroro and Okoh, 2010). Phytochemical screening is a process in which the extraction, identification and screening of phytochemicals can be done easily for variety of medicinal plants (Syed et al., 2013). As these phytochemicals are precursors for the synthesis of various new drugs (Syed et al., 2013).

Terpenoids is an oldest biomolecules and very diverse in nature, found abundant in nature and is very much known for its anti-fungal, anti-inflammatory, anti-bacterial properties (Amany et al., 2012). Alkaloids are the best anaesthetic agents used in various surgical practices and their properties have been described in various pharmacological activities like anti-cancer, anti-malaria, antiasthama (Aiyelaagbe and Osamudiamen, 2009). Flavonoids are known as anti-oxidants and stimulate several health effects (Okwu et al., 2005).

Due to the above known properties of phytochemical constituents and their infinite physiological actions, we have selected the three medicinal plants for our present study, Carica papaya commonly known as the papaya belongs to the family of Caricaceae, is one of the 22 accepted species of genus Carica which is dioecious in nature, originated from tropics of America, Southern Mexico and neighbouring Central America. It provides 43 kilocalories, rich in vitamin $\mathrm{C}$, and its pulp contains $88 \%$ water and $11 \%$ carbohydrate (Ayoola et al., 2008). Agave americana commonly known as the century plant or American aloe is belongs to the family of Agaveceae and is the species of genus Agave is widely distributed in Europe, South Africa, India, Australia. Traditionally, it has been studied that its roots have diuretic and antisyphilitic properties. It has wide range of pharmacological properties and used for the same purposes (antiseptic, wound healing and anti-inflammatory properties) (Kadam et al., 2011). Piper nigrum common name is Black pepper/kali mirchi belongs to the family of Piperaceae is a monocious or decorous climbing vine native of Southern India and Srilanka and elsewhere in tropical regions is bountifully cultivated there. Alkaloids are often toxic to man and many have dramatic physiological activities; hence their wide use in medicine (Amany et al., 2012; Ayoola et al., 2008; Ajuko et al., 2007). Among the plants investigated till date, medicinal plants belongs to the family of piperceae have enormous potential (Sahu, 2011). An alkaloid piperine found naturally in plants belongimg to the pyridine group of Piperaceae family, such as Piper nigrum and Piper cubeba. It is widely used in cough syrups, antiinflammatory, anti-malarial, anti-leukemia treatment (Sahu, 2011). Recent medical studies have shown that it is helpful in increasing the absorption of certain vitamins, selenium, $\beta$-cartene, also increase the body's natural thermogenic activity (Sahu, 2011; Amany et al., 2012). All the parts of the above mentioned medicinal plants are very effecacious and widely used in pharmacological activities specially their leaves, roots, barks, stems (Talaly and Talaly, 2001; Sofowara, 1993).

The main objective of our research work was to analyze the presence or absence of different types of phytochemical constituents in two different parts i.e. leaves and roots of three medicinal plants Carica papaya, Piper nigrum, Agave americana. We had performed the comparative study of phytochemical constituents on the basis of their presence or absence, as they are used in curing various diseases (Aiyelaagbe and Osamudiamen, 2009; Erum Iqbal, 2015; Harborne, 1998). 


\section{Materials and Methods}

\section{Plant materials}

The present study included plant species which were Carica papaya (Papaya), Piper nigrum (Black Pepper / Kali Mirchi), Agave americana (Century Plant), leaves and roots of these plants were extracted for the phytochemical screening analysis.

\section{Sample collection and identification of plant materials}

For the present study fresh leaves and roots of $C$. papaya, $P$. niger, A. americana were collected from the nursery of Jor bagh, New Delhi. The plants were identified by the Dr. Pallavi Singh of the Department of Biotechnology, Faculty of Biotechnology (our Project Guide).

The plant materials were washed with running tap water, then with distilled water to make it sterile free from any kind of contamination it was washed with $95 \%$ ethanol. All the plant materials were shade dried until all the water molecules were evaporated and plant became well dried for grinding, with the help of mortar and pestle all the plant parts ground well in to fine powder form and the stored in the polyethene bag with proper labelling.

\section{Preparation of plant extract}

\section{Aqueous extract}

For the preparation of Aqueous extract, One gram $(1 \mathrm{~g})$ of dried powder of experimental material of both the leaves and roots were soaked in $20 \mathrm{~mL}$ of water for $24 \mathrm{hrs}$ and kept in shaking incubator at $50-60 \mathrm{rpm} \& 40^{\circ} \mathrm{C}$. The mixture was then filtered through the Whatmann No.1filter paper to ensure that no particles were present in the solution and the extract was collected.

\section{Methanolic extract}

For the preparation of Methanolic extract, One gram $(1 \mathrm{~g})$ of powdered material of both the leaves and roots were soaked in $20 \mathrm{~mL}$ of methanol and kept at shaking incubator at 50$60 \mathrm{rpm} \& 40^{\circ} \mathrm{C}$ for $24 \mathrm{hrs}$. The mixture was then filtered with Whatmann No. 1 filter paper and the extract was collected.

\section{Phytochemical screening}

Each dry extract was used for screening the following bioactive compounds: alkaloids, terpenoids, phenol and tannins, sugar, saponins, flavonoids, quinones, and proteins, according to the standard procedure described by (Ayoola et al., 2008).

\section{Alkaloids test \\ $1 \mathrm{ml}$ of extract was mixed with $1 \mathrm{ml}$ of Mayer's reagent and few drops of iodine solution also added, the formation of yellow colour indicates the presence of alkaloids.}

\section{Terpenoids test}

$1 \mathrm{ml}$ of extract was mixed with $1 \mathrm{ml}$ of Conc.H2SO4 and incubated in water bath for 2-4 minutes, the formation of greyish colour indicates the presence of terpenoids.

\section{Tests for phenols and tannins}

$1 \mathrm{ml}$ of extract was added to $1 \mathrm{ml}$ of $2 \%$ $\mathrm{FeCl}_{3}$.The formation of blue, green or black colour indicates the presence of tannins.

\section{Tests for Sugar}

$1 \mathrm{ml}$ of benedict's solution is mixed with $1 \mathrm{ml}$ of extract. Sample is then incubated in a water bath for 2-4minutes. The presence of red, orange, blue or green color shows the presence of sugar. 


\section{Tests for saponins}

$1 \mathrm{ml}$ of extract was mixed with 1 to $2 \mathrm{ml}$ of distilled water, the formation of $1 \mathrm{~cm}$ foam layer indicates the presence of saponins.

\section{Flavonoids test}

Add few drops of dilute $\mathrm{NaOH}$, in $1 \mathrm{ml}$ of extract, neutralize the solution by adding few drops of $\mathrm{HCl}$. The sample will discolour indicating the presence of flavonoids

\section{Tests for quinones}

Add few drops of dilute $\mathrm{NaOH}$, in $1 \mathrm{ml}$ of extract, neutralize the solution by adding few drops of $\mathrm{HCl}$. The sample will discolour indicating the presence of flavonoids.

\section{Tests for proteins}

Few drop of Conc. nitric acid was added to $1 \mathrm{ml}$ of extract, the formation of yellow colour indicates the presence of proteins.

\section{Results and Discussion}

The phytochemical screening of crude methanolic \& aqueous extract of leaves and roots sample of Carica papaya, Piper nigrum, Agave americana revealed the presence or absence of some secondary metabolites (phytochemical constituents) such as alkaloids, terpenoids, flavonoids, sugar, protein, phenols, saponins, quinones as shown in Table 1.

According to the present study an aqueous extract of medicinal plants showed the presence of terpenoids in Piper nigrum leaves but it is not seen in the Piper nigrum roots. Tannins are only detected in Carica papaya leaves and it is not seen in Carica papaya roots. Quinones showed the best result in Agave americana root aq. extract. All the three medicinal plants have the presence of alkaloids in their aqueous root extract. Sugar, proteins, flavonoids are found in abundant amount they are detected in all the three medicinal plants.

Whereas, the crude methanolic extract of leaves and roots showed different results for saponins, saponin is not present in the aqueous extract but in methanolic extract of Piper nigrum roots it has been detected. Phytochemical constituents alkaloids, flavonoids, sugar, proteins were present in the methanolic extract of leaves and roots as shown in Table 2.

Medicinal and healing properties of herbs are closely related to their chemical constituents which are classified into some major groups like alkaloids, terpenoids, phenols, tannins, sugar, proteins, quinones, saponins and getting these chemicals out into the herbal remedy depends upon the solubility of these components in various solvents (Hara et al., 1998; Monisha et al., 2017; Nisa et al., 2013). For example, Alkaloids have been reported as powerful poison and many alkaloids derived from medicinal plants show biological activities like anti-inflammatory, anti-malarial, anti-microbial, cytotoxicity and pharmacological effects (Nayan et al., 2016).

Tannins, according to research, are known to have anti-bacterial, anti-tumor and antiviral activities. They work by precipitating microbial protein thus making nutritional protein unavailable for them (Sofowara, 1993). The phytochemical constituents and their presence in different parts of various medicinal plants give the pharmacologist a scope of work to do work on them for the formation of new drugs (Syed et al., 2013). The presence of these chemical components in three medicinal plants helps to evolve the concept that they are best suited for medicinal and curing purposes. 
Table.1 Phytochemical constituents in aqueous extracts of three medicinal plants

\begin{tabular}{|l|l|l|l|l|l|l|}
$\begin{array}{l}\text { Phytochemical } \\
\text { tests }\end{array}$ & $\begin{array}{l}\text { Papaya } \\
\text { leaves }\end{array}$ & $\begin{array}{l}\text { Piper } \\
\text { leaves }\end{array}$ & $\begin{array}{l}\text { Agave } \\
\text { leaves }\end{array}$ & $\begin{array}{l}\text { Papaya } \\
\text { roots }\end{array}$ & $\begin{array}{l}\text { Piper } \\
\text { root }\end{array}$ & $\begin{array}{l}\text { Agave } \\
\text { root }\end{array}$ \\
\hline Alkaloids & - & - & - & + & + & + \\
\hline $\begin{array}{l}\text { Terpenoids } \\
\text { Phenol \& }\end{array}$ & + & + & - & - & - & - \\
\hline tannin & & - & - & - & - & - \\
\hline Sugar & + & + & + & + & + & + \\
\hline Saponins & - & - & - & - & - & - \\
\hline Flavonoids & + & + & + & + & - & - \\
\hline Quinones & - & - & - & - & - & + \\
\hline Proteins & + & + & + & + & + & + \\
\hline
\end{tabular}

Table.2 Phytochemical constituents in methanolic extract of three medicinal plants

\begin{tabular}{|l|l|l|l|l|l|l|}
$\begin{array}{l}\text { Phytochemical } \\
\text { tests }\end{array}$ & $\begin{array}{l}\text { Papaya } \\
\text { leaves }\end{array}$ & $\begin{array}{l}\text { Piper } \\
\text { leaves }\end{array}$ & $\begin{array}{l}\text { Agave } \\
\text { leaves }\end{array}$ & $\begin{array}{l}\text { Papaya } \\
\text { roots }\end{array}$ & $\begin{array}{l}\text { Piper } \\
\text { root }\end{array}$ & $\begin{array}{l}\text { Agave } \\
\text { root }\end{array}$ \\
\hline Alkaloids & + & + & + & & + & \\
\hline $\begin{array}{l}\text { Terpenoids } \\
\text { Phenol \& }\end{array}$ & + & - & - & - & - & - \\
\hline $\begin{array}{l}\text { tannin } \\
\text { Sugar }\end{array}$ & + & - & - & - & - & - \\
\hline Saponins & - & + & + & + & + & + \\
\hline Flavonoids & - & - & - & - & + & - \\
\hline Quinones & - & - & + & + & - & - \\
\hline Proteins & + & + & + & - & - & - \\
\hline
\end{tabular}

Fig.1 Phytochemical analysis of Carica papaya root (a) aqueous extract (b) Methanolic extract
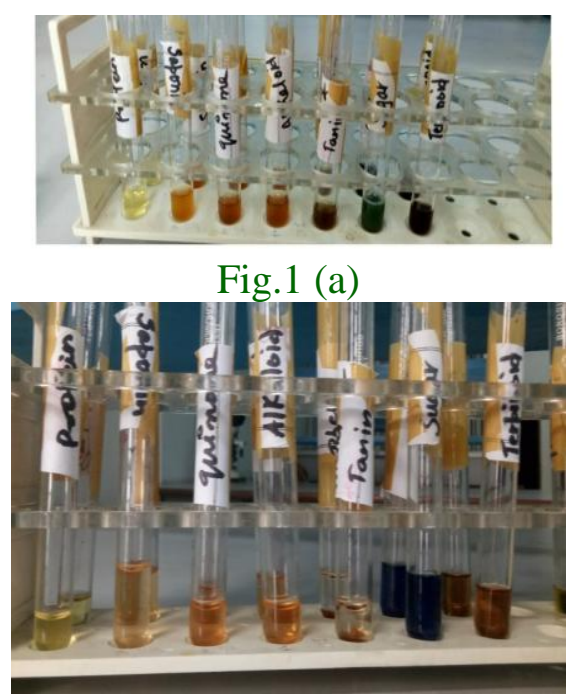

Fig.1 (b) 
Fig.2 Phytochemical analysis of Carica papaya leaves (a) aqueous extract (b) Methanolic extract

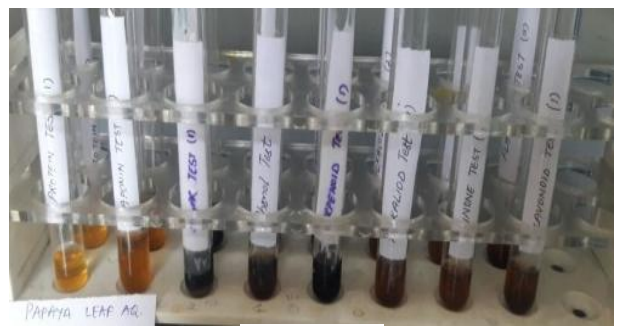

Fig.2 (a)

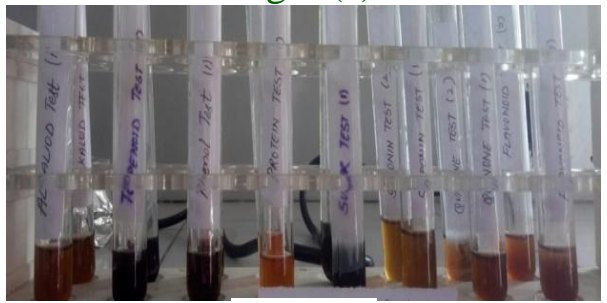

Fig.2 (b)

Fig.3 Phytochemical analysis of Piper nigrum leaves (a) aqueous extract (b) Methanolic extract

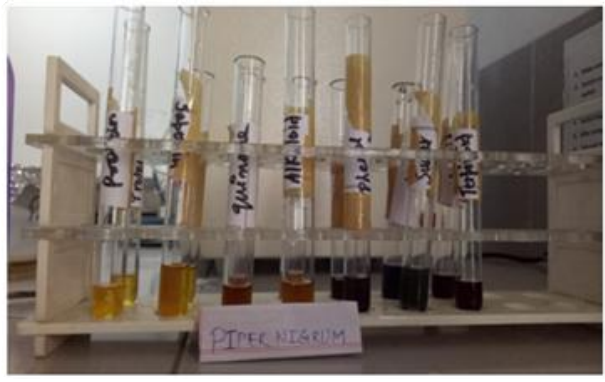

Fig.3 (a)

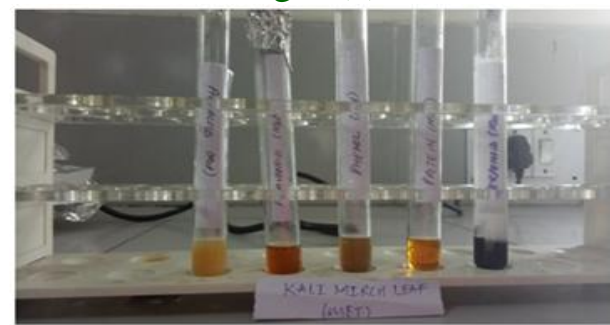

Fig.3 (b)

Fig.4 Phytochemical analysis of Piper nigrum roots (a) aqueous extract (b) Methanolic extract

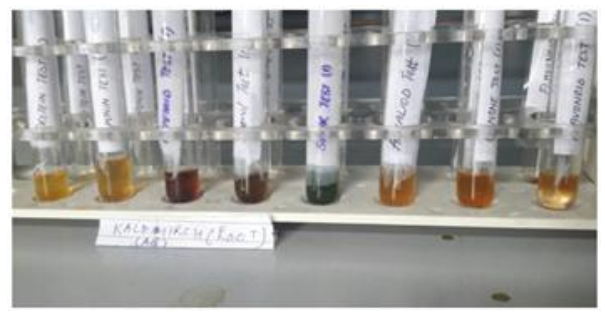

Fig.4 (a) 


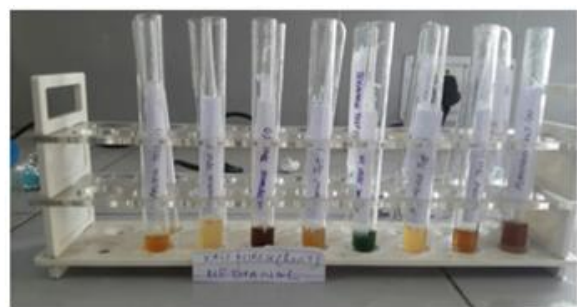

Fig.4 (b)

Fig.5 Phytochemical analysis of Agave americana roots (a) aqueous extract (b) Methanolic extract

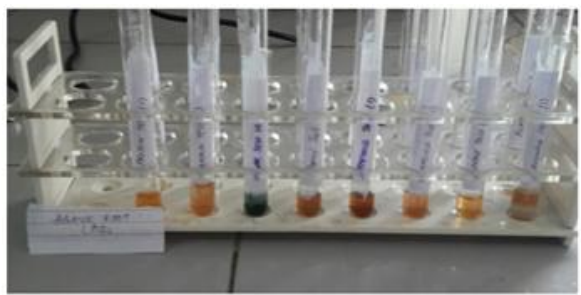

Fig.5 (a)

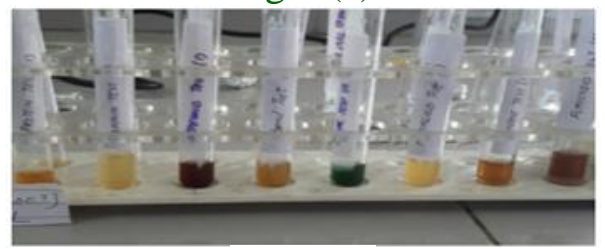

Fig.5 (b)

Fig.6 Phytochemical analysis of Agave americana leaves (a) aqueous extract (b) Methanolic extract

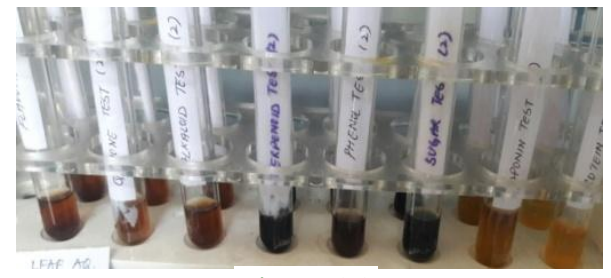

Fig.6 (a)

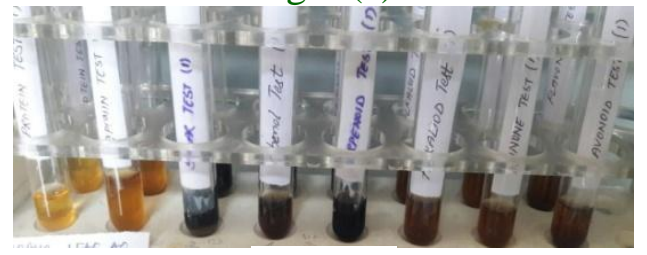

Fig.6 (b)

The results revealed the presence of important medicinal components in the plants studied. Our results show that $C$. papaya, $P$. nigrum, $A$. americana can serve as potential source of bioactive healthy compounds in the diet and their consumptions could be useful in the prevention of various diseases. Therefore, extracts of these plants could be best source 
for various new drugs. Several of such compounds are known to have the presence of potent antioxidant activity. So this research work also supports for the use of these fruits in pharmaceutical industries as a natural antioxidant also. Thus, we hope that the present study of our research work will be helpful in copping the several diseases ailments of specific regions (Figs. 1-6).

Also additional work is encouraged to elucidate the possible anti-microbial efficacy with different species of microorganisms.

\section{References}

Abdullahi, M.N., Ilyas, N., Ibrahim, H., 2013. Evaluation of phytochemical screening and analgesic activity of aqueous extract of the leaves of Microtrichia perotitii dc (Asteraceae) in mice using hotplate method. Med. Plant Res. 3, 3743.

Aiyegroro, O.A., and Okoh, A.I. 2010. Preliminary phytochemical screening and in vitro antioxidant activities of aqueous extract of Helichrysum longifolium DC. BMC compl. And Alt. Med., 10.

Aiyelaagbe, O.O., and Osamudiamen, P.M., 2009. Phytochemical screening for active compounds in Mangifera indica leaves from Ibadan, Oyo State. Plant Sci. Res. 2, 11-13.

Ajuko, G.A., et al., 2007. Preliminary phytochemical and antimicrobial screening of 50 medicinal plants from Nigeria. African Journal of Biotechnology, 6(14), 1690-1696.

Amany et al., 2012. In vitro: Antimicrobial potential and phytochemical screening of some Egyptian aquatic plants.

Ayoola et al., 2008. Phytochemical Screening and Antioxidant Activities of Some Selected Medicinal Plants Used for Malaria Therapy in Southwestern
Nigeria. Tropical Journal of Pharmaceutical Research, September 2008; 7 (3): 1019-1024.

Erum Iqbal et al., 2015. Phytochemical screening, total phenolics and antioxidant activities of bark and leaf extracts of Goniothalamus velutinus (Airy Shaw) from Brunei Darussalam. Journal of King Saud University Science (2015) 27, 224-232.

Hara, O.M., Keifer, D., Farrel, K., Kemper, K., 1998. A review of 12 commonly used medicinal herbs. Arch. Fam. Med. 7, 523-536.

Harborne J.B. Phytochemical Methods, a guide to modern techniques of plant analysis, 3rd Edn. Springer (India) Private Limited, New Delhi (1998).

Harborne, J.B., 1973. Phytochemical Methods. Chapman and Hill, London. London. Ltd. pp. 49-188.

Kadam P et al., 2011; Pharmacognostic and Phytochemical Studies on Roots of Agave americana (Agavaceae). International Journal of Pharmacognosy and Phytochemical Research 2012; 4(3): 92-96.

Monisha et al., 2017. Extraction of Bio Active Compounds from Cassia Auriculata Pods and Leaves and its Medicinal Uses.

Munin et al., 2011. Phytochemical analysis of some medicinal plants. Journal of Phytology, 2011, 3(12): 10-14.

Nayan et al., 2016; Phytochemical Analysis of Traditional Medicinal Plants and their Antimicrobial Activity: An Experience from North East India

Nisa, H., Kamili, A.N., Bandh, S.A., Shajr-ulAmin, Lone, B.A., Parray, J.A., 2013. Phytochemical screening, antimicrobial and antioxidant efficacy of different extracts of Rumex dentatus L. - A locally used medicinal herb of Kashmir Himalaya. Asian Pac. J. Trop. Dis. 3(6), 434-440. 
Obdoni BO, Ochuko PO (2001). Phytochemical studies and comparative efficacy of the crude extracts of some Homostatic plants in Edo and Delta States of Nigeria. Global J. Pure Appl. Sci. 8b: 203-208

Okeniyi et al., 2007; Phytochemical screening

Okwu DE, Okwu ME (2004) Chemical composition of Spondias mombin Linn. Plants parts.

Okwu et al., 2005; Phytochemical constituents of some Nigerian medicinal plants. African Journal of Biotechnology Vol. 4 (7), pp. 685-688.

Parekh, J., and Chanda, S. 2008. Phytochemicals screening of some plants from western region of India. Plant Arch., 8: 657-662.

Prashant Tiwari et al., 2011; Phytochemical screening and Extraction: A Review

Priyanka tripathi et al., 2011; Phyllanthus amarus: Ethnomedicinal uses, phytochemistry and pharmacology: A review. Journal of Ethnopharmacology 138 (2011) 286-313

Rahila T, Rukhsandra N, Zaidi AA, Shamishilia R (1994). Phytochemical
Screening of medicinal plants belonging to Euphorbiaceae Pak. Vet. J. 14: 160162.

Rawan et al., 2013. Antibacterial activity and phytochemical screening of some medicinal plants commonly used in Saudi Arabia against selected pathogenic microorganisms. Journal of King Saud University - Science (2013) 25, 115-120.

Sahu, R.K., Phytochemical Evaluation and Antioxidant activity of Piper cubeba and Piper nigrum Journal of Applied Pharmaceutical Science 01 (08); 2011: 153-157.

Sofowara A. Medicinal plants and Traditional medicine in Africa. Spectrum Books Ltd, Ibadan, Nigeria. (1993) 289.

Syed et al., 2013; Phytochemical Analysis of Medicinal Plants Occurring in Local Area of Mardan. Wadood et al., Biochem Anal Biochem 2013, 2:4

Talaly, P., and Talaly, P., 2001. The importance of using scientific principles in the development of medicinal aspects of plants. Acad. Med. 76, 238-247.

\section{How to cite this article:}

Pallavi Singh, Nainika Tanwar, Trisha Saha, Aishwarya Gupta and Sargam Verma. 2018. Phytochemical Screening and Analysis of Carica papaya, Agave americana and Piper nigrum. Int.J.Curr.Microbiol.App.Sci. 7(02): 1786-1794. doi: https://doi.org/10.20546/ijcmas.2018.702.216 